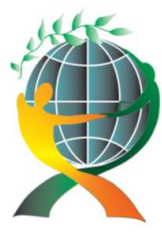

\author{
(online) $=$ ISSN $2285-3642$ \\ ISSN-L = $2285-3642$ \\ Journal of Economic Development, Environment and People \\ Volume 7, Issue 1, 2018 \\ URL: http://jedep.spiruharet.ro \\ e-mail: office jedep@spiruharet.ro
}

\title{
Supporting SMEs in creating jobs
}

\author{
Daniela Pașnicu \\ Spiru Haret University (USH), National Scientific Research Institute for Labor and Social Protection \\ (INCSMPS)
}

\begin{abstract}
SMEs are the most dynamic sector of the economy, representing a key factor in employment growth. Although SMEs have been severely affected by the economic crisis from 2008, they continue to be an more and more important source of generating jobs, regardless of size class. Given the differentiated contribution of SMEs to job creation as a result of their heterogeneity, the article analyses the dynamics of staff in enterprises by size classes and activities of the national economy. The statistical analysis is followed by a SWOT analysis of policies and tools to support SMEs in creating jobs both with direct action management, recruitment, training and indirectly action by addressing general business issues. Supporting measures of the economic growth of SMEs through internationalization, innovation and improved access to finance foster competitiveness and, implicitly, the creation of new jobs.
\end{abstract}

Keywords: SMEs, employment, jobs, policies

JEL Codes: J00, J08, J21, M5

\section{Introduction}

SMEs are considered the "backbone" of the economy at EU level, given that: they represent 99 out of every 100 companies in Europe; hold two-thirds of the number of workers and the company's net contribution to the economy (net benefit) is 58 cents per euro. At EU level, 9 out of 10 SMEs are microenterprises. SMEs in five key sectors (manufacturing, construction, business services, hotels-restaurants and trade) hold $78 \%$ of SMEs in the EU, $71 \%$ of value added and $79 \%$ of SMEs [1]. By sectors of activity at European level, the highest job losses resulting from the global crisis occurred in the manufacturing and construction sectors; while in other areas there was a sustained increase in employment levels, especially in large categories of professional services (legal services, engineering, accounting) and administrative services (employment, security, tourism and building services) - sectors where a large proportion of employees work in SMEs [2].

The economic crisis has negatively influenced the number of SMEs and their employees to a greater extent in Romania compared to the average in Europe. In the period 2008-2015, the number of SMEs grew in Europe by almost $2 \%$ and the number of employees decreased by $1 \%$; in Romania the number of SMEs decreased by $10 \%$ and the number of employees decreased by $7.5 \%$. The average number of employees in SMEs in 2015 was 4.12 in Europe and 5.69 in Romania. Small enterprises recorded the lowest decrease in 


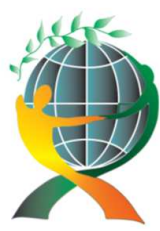

\author{
(online) $=$ ISSN $2285-3642$ \\ ISSN-L = $2285-3642$ \\ Journal of Economic Development, Environment and People \\ Volume 7, Issue 1, 2018 \\ URL: $\underline{\text { http://jedep.spiruharet.ro }}$ \\ e-mail: office jedep@spiruharet.ro
}

Romania in the analysed range, both in number (0.3\%) and as employees (3.2\%). There are, therefore, large gaps at Member State level that need to be recovered.

The crucial importance of SMEs in economic development is recognized at EU level through the adoption of the Small Business Act (SBA) in 2008 [3]. This law outlines a global framework for EU policy concerning SMEs to improve entrepreneurship in Europe, simplify the regulatory environment and policies for SMEs, and remove remaining obstacles to their development. The main priorities are to promote entrepreneurship, better regulation, access to finance and access to markets and internationalization.

In the case of Romania, public policy recognizes the importance of SMEs in economic development and the labor market, with various support instruments, both directly, through national and European funds, and indirectly, by shaping a favorable regulatory framework.

Among the regulatory initiatives, we mention:

- The Governmental Strategy for the Small and Medium Enterprises Sector and Development and the Improvement of the Romanian Business Environment;

- National Competitiveness Strategy;

- POCU - Human Capital Operational Plan;

- Emergency Ordinance no. 44/2008 on the carrying out of economic activities by authorized individuals, individual and family enterprises with subsequent amendments and completions;

- Law no. 31/1990 on the organization and functioning of the companies with subsequent amendments and completions;

- Law no. 346/2004 on the stimulation of the establishment and development of small and medium enterprises, with subsequent amendments and completions;

- Emergency Ordinance no. 6/2011 to stimulate the setting up and development of micro enterprises by young entrepreneurs, as subsequently amended and supplements;

- The new Tax Code - Law no. 227/2015 on the Fiscal Code (in force since 1 January 2016); The Law of the Debutant Entrepreneur - Law no. 97/2014.

Although sustained efforts are being made to improve the legislative framework, some authors believe that the current SMEs policy is a mix of contrasting issues, given that annual consistent amounts were invested compared with Romania's GDP, but there is not some consensus on efficiency or results [6]. The need to improve the future of the business environment results also from the conclusions of the SMEs perception survey, namely the small share of companies that consider the evolution of the business environment to be favourable (18.16\%) and the large share of companies experiencing difficulties regarding: excessive taxation (54.74\%); corruption (45.16\%); excessive controls (44.98\%); unfair competition (40.33\%); decrease in domestic demand (36.31\%); hiring, training and maintaining staff (26.37\%); increase in salary expenditure (25.54\%); inflation (21.9\%); competition of imported products $(19.71 \%)$; delays in collecting invoices from private companies $(19.62 \%)$; poor infrastructure quality (18.16\%); high credit costs (15.24\%) and relative instability of the national currency (13.14\%) [7]. 


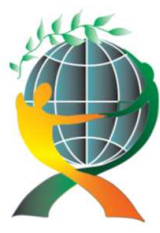

\author{
(online) $=$ ISSN $2285-3642$ \\ ISSN-L = $2285-3642$ \\ Journal of Economic Development, Environment and People \\ Volume 7, Issue 1, 2018 \\ URL: $\underline{\text { http://jedep.spiruharet.ro }}$ \\ e-mail: office jedep@spiruharet.ro
}

\title{
2. Dynamics of SME staff by size classes and activities of the national economy
}

In 2015, approximately 3 million employees representing $72 \%$ of the total number of employees were employed in the Romanian SMEs operating in the sectors of industry, construction, trade and other activities. According to size classes, the structure of SMEs is relatively balanced, with the number of employees in small enterprises accounting for the highest share in 2015 , i.e. $34.1 \%$ of the total number of employees working in SMEs, while in the other classes the share was $33.3 \%$ in microenterprises, respectively $32.7 \%$ in medium-sized enterprises (50-249 persons). It can be seen that the employees from the small enterprises were the least affected by the economic crisis and that they recovered the fastest: the share of employees in small enterprises in the structure of SMEs increased by $2.4 \mathrm{pp}$ in 2015, compared to 2008, with an increasing trend over the whole period. This increase was felt proportionally by the employees of the other two size classes, their weight decreasing by $1.2 \mathrm{pp}$. in the case of medium-sized firms and with $1.2 \mathrm{pp}$. in the case of small firms.

Graph 1. Structure of employees in SMEs by size classes

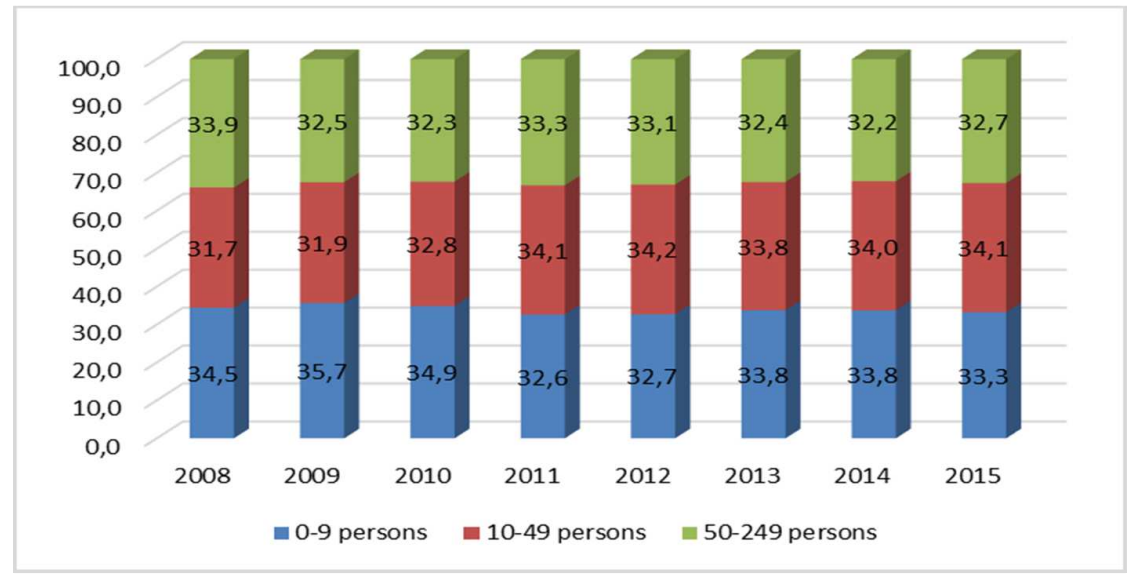

Source: Author processing by INSSE data, TEMPO Online

The level of employment is below that registered in 2008 throughout the analyzed range (20082015) for all enterprises, regardless of the size class. The impact of the labor market crisis in the analyzed range peaked in 2010, with a minimum number of employees as compared to 2008 for all size classes except for micro-enterprises that reached a minimum in 2011: SMEs there was a fall in employment of $14.5 \%$, lower than that recorded by large enterprises (-17.9). Within the SMEs structure, the largest decreases were registered in the size class of medium-sized enterprises (18.5\%). Although in the analyzed seven-year period there is a slight improvement in employment after the economic crisis, however, in 2015 there is a $10 \%$ lower employment rate compared to 2008. On size classes, we observed that the employment level in small enterprises has been the least affected by the economic crisis and has best recovered afterwards; at the opposite end are medium-sized businesses.

Another observation is that the average number of employees in SMEs has decreased due to the higher growth rates of the number of SMEs compared to the number of employees. Therefore, there is a need for the development of existing SMEs, stimulating measures to create new jobs in existing businesses. 


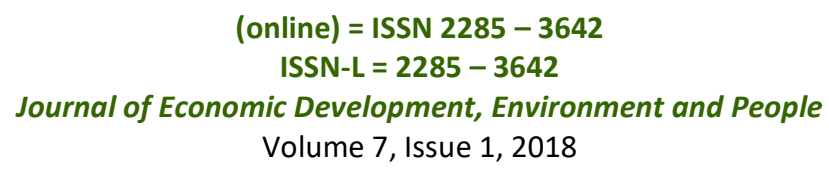

URL: http://jedep.spiruharet.ro

e-mail: office jedep@spiruharet.ro

Graph 2: Change in the number of employees in enterprises by size class compared to $2008(2008=100)$

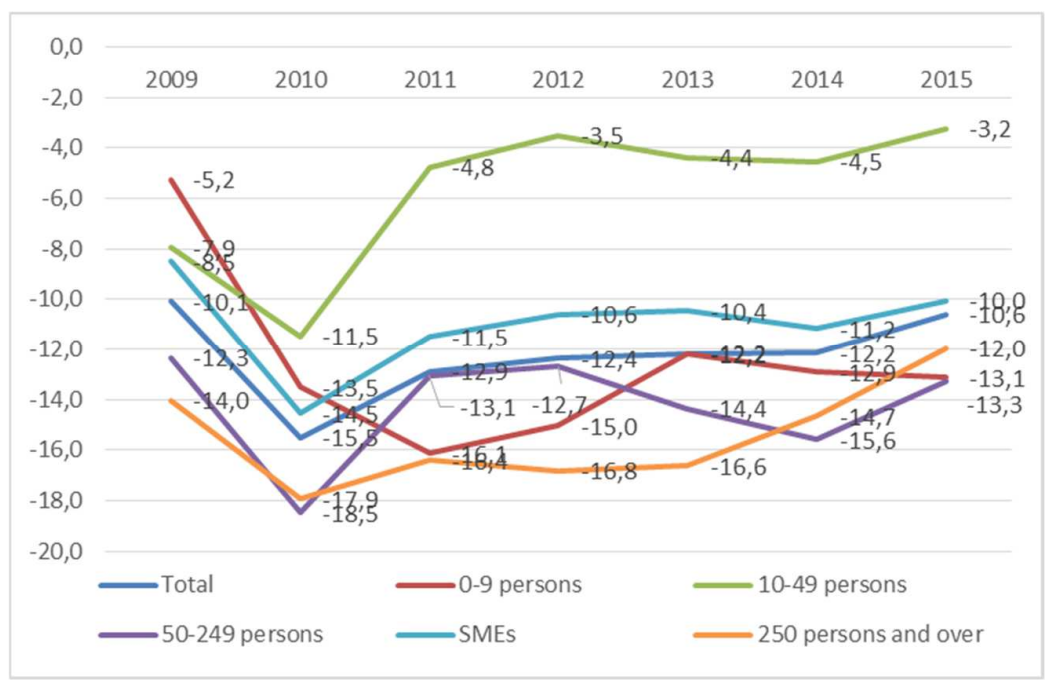

Source. Author processing by INSSE data, TEMPO Online

Graph 3: Indicators on the evolution of the number of SMEs and employees

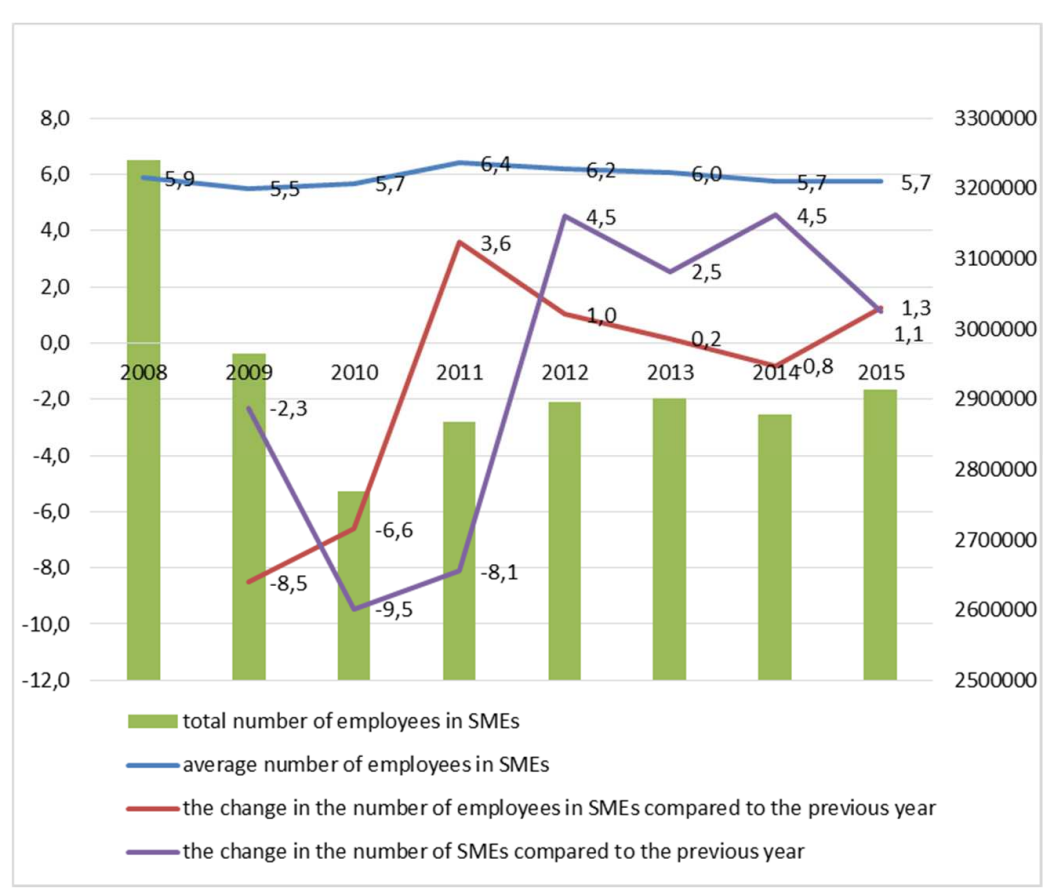

Source: Author processing by INSSE data, TEMPO Online 


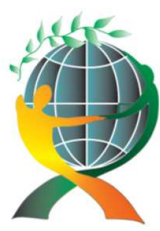

\author{
(online) $=$ ISSN $2285-3642$ \\ ISSN-L = $2285-3642$ \\ Journal of Economic Development, Environment and People \\ Volume 7, Issue 1, 2018 \\ URL: http://jedep.spiruharet.ro \\ e-mail: office jedep@spiruharet.ro
}

In Romania, the economic crisis has a strongly influence in businesses in the Micro, Small and Medium Enterprises (SME) sector, with over $40 \%$ entering insolvency or bankruptcy. Most active SMEs are in the Commerce / Repair of Motor Vehicles \& Motorcycles (34\%). The other four fields of activity in the top 5 are Professional / Scientific / Technical Activities, Construction, Manufacturing and Transport / Storage. The top five domains account for $71 \%$ of all active SMEs. The last five positions in the top of the list, depending on the field of activity of SMEs, are the fields of financial intermediation / insurance, cultural / recreational performances, education, production / supply of electricity / gas etc .; and waste management - 6\% [6].

\title{
3. The SWOT analysis of Romania's strategies, policies, measures for the development of SMEs in terms of the effects on employment
}

\section{Strengths}

- the existence of areas of activity with competitive potential to which SMEs have made an important contribution, such as: the electrical and electronic equipment sector, the automotive sector, the garment industry, the food industry, the furniture industry, as well as smart specialization areas, such as bio-economy, information and communication technologies, energy and the environment, eco-technologies, etc.

- improving the existing regulatory framework with new development measures for SMEs that directly target the quality of the workforce, such as: stopping the net loss of labor with a better employment rate; development of the agricultural sector; increasing the contribution of the social economy as a basis for competitive development; increasing the number of employees benefiting from standard tools, methods, standard human resource management practices and improved working conditions; providing financial support to individuals for setting up business; increasing the emphasis on innovation; generation 2050 training; provision of personalized counseling / consulting services;

- grants to create new jobs in existing SMEs;

- starting a new financial exercise 2014-2020, taking advantage of the experience gained in the previous exercise and the simultaneous review of all strategies;

- debate on regionalization / decentralization, the existence of a stable macroeconomic framework and a governmental commitment to strategic investment and job creation;

- a high natural agricultural potential as a sustained dynamics of entrepreneurship;

- central government efforts to create a favorable business environment;

- a high potential for using renewable energy and increasing energy efficiency.

\section{Weaknesses}

- the lack of close collaboration with other businesses, trade unions, academia, NGOs, consumer organizations to identify bottlenecks and developing a joint analysis on how to maintain a solid industrial base and knowledge;

- Insufficient promotion of vocational education and entrepreneurial culture;

- the low number and density of SMEs per 1000 inhabitants; 


\author{
(online) $=$ ISSN $2285-3642$ \\ ISSN-L = $2285-3642$ \\ Journal of Economic Development, Environment and People \\ Volume 7, Issue 1, 2018 \\ URL: http://jedep.spiruharet.ro \\ e-mail: office jedep@spiruharet.ro
}

- the low number and density of SMEs in rural areas; of the 450,000 SMEs active at national level (2011), only $14 \%$ operate in rural areas, mainly micro-enterprises, unable to absorb excess labor and having a minimal market contribution; the small population density of rural SMEs, ie 7 SMEs / 1000 inhabitants, six times lower than the European average (42 SMEs / 1000 inhabitants in Europe) and three times lower than the national average; existing rural SMEs fail to make a significant contribution to the sustainable economic development of rural areas, as long as there is not a sufficient number of firms and a favourable environment for their establishment and development [5];

- insufficient stimulation of R \& D and innovation activities in SMEs;

- insufficient encouragement of public-private partnership;

- a small number of people / debutants decide to start a business on their own as compared to the number of other countries. In Romania, 1 out of 100 debutants decide to start a business, compared to 1 in 4 in the Czech Republic, Poland or Hungary and only few of them start a business on their own, motivating lack of money and bureaucracy.

- low innovation performance as a result of a national RDI system in development stage, characterized by poor cooperation between research and business; low RDI spending (as a percentage of GDP); timely connections to the international environment; reduced transfer of CD results to the private environment; reduced $R$ \& D demand from the private environment; low literacy in informatics of the population and use of ICT in SMEs;

- the development of competitive advantages is reduced in the case of services, and in the territorial level it is unbalanced, with significant exports being concentrated in 7 counties located in the West and the centre of the country and Bucharest (60\% of Romania's exports)

- poor managerial capacity of SMEs, especially in small firms, requiring the provision of personalized counseling / consulting services (e.g. business plan, legal advice, accounting, marketing, business improvement, business development etc.) and work conditions improved in view of adapting activity to the dynamics of competitive economic sectors;

\title{
Threats
}

- economic structures that did not carry out major transformation processes, with structural weaknesses in the economy and employment;

- macroeconomic risk factors, such as low tax collection, black economy propagation, pension system precarious, etc;

- the high risk aversion of SMEs as a result of a very small percentage of SMEs investing in their first year of activity; a high percentage of 59\% of newly created enterprises with no employees; it therefore follows that the entrepreneurial inclination does not lead to proportional increases in employment;

- $\quad$ unattractive business infrastructure: poorly developed and untapped transport routes, energyintensive industrial capacities, excessive bureaucracy, high labor force in agriculture [5], reduced funding through non-bank organisms; 


\author{
(online) $=$ ISSN $2285-3642$ \\ ISSN-L = $2285-3642$ \\ Journal of Economic Development, Environment and People \\ Volume 7, Issue 1, 2018 \\ URL: http://jedep.spiruharet.ro \\ e-mail: office jedep@spiruharet.ro
}

- Failure to meet strategic targets by 2020, proposed in the Governmental Strategy for Small and Medium-Sized Enterprise Development and Improving the Romanian Business Environment

670,000 - number of active SMEs (increase by $41,23 \%$ )

36,45 - number of active SMEs per 1000 inhabitants (increase by 51,50\%)

$3,233,000$ - total number of employees in active SMEs (increase by $23.23 \%$ )

- special social problems affecting the activity of SMEs in Romania: high share of the population in poverty and risk of social exclusion; the highest rate of school drop-out at European level; the low share of the population with higher education; the aging of the population; in-work poverty [4]; the migration of young people and, in particular, of those qualified and of higher performance; decrease in birth rates; low level of labor education;

- high values of the corruption index (respectively 48/2017) compared to the other EU countries, except for Bulgaria and Hungary.

\title{
Opportunities
}

- supporting the extensive and intensive growth of the SME sector, with an emphasis on increasing the number of active SMEs at local and external markets of interest;

- increasing the density of SMEs, especially in areas where they are below the European average, in order to reduce current regional disparities;

- stimulating economic activity in line with employment potential in rural areas;

- stimulating associative forms to increase the bargaining power of SMEs;

- Improving the quality and efficiency of public services for setting up and running businesses - one stop shop;

- better information on SME legislation;

- developing and implementing programs and campaigns to promote entrepreneurial culture in rural areas with special attention to young people and women;

- promoting and supporting the revitalization and development of traditional crafts;

- SMEs access to adequate funding;

- stimulating innovative SMEs based on research development. Among the policies and measures that address this issue, we mention: organizing and conducting $R \& D$ and innovation activities by small and medium enterprises; creating a favorable environment for the dissemination, transfer, absorption and exploitation of the results of the research and development activity and innovation; capitalizing and absorbing the results of the innovation activity, as well as the technological transfer at the level of small and medium enterprises; ensuring the improvement of the access of small and medium enterprises to specialized scientific and technological information; setting up business incubators, science and technology parks and other similar infrastructures; the provision of technology transfer free of charge to small and medium-sized enterprises;

- improving access to markets and the internationalization of SMEs; 


\author{
(online) $=$ ISSN $2285-3642$ \\ ISSN-L = 2285 - 3642 \\ Journal of Economic Development, Environment and People \\ Volume 7, Issue 1, 2018 \\ URL: http://jedep.spiruharet.ro \\ e-mail: office jedep@spiruharet.ro
}

- establishing and developing networks and partnerships to facilitate the exchange and integration of good practices, such as: study visits; organizing seminars and conferences, including aspects of motivating and mobilizing people in rural areas for employment; organization of the labor market and service sector in rural areas; diversification of the rural economy; promoting equal opportunities; environmental protection and cultural heritage in the countryside, etc.;

- support for the development and implementation of integrated strategies for the development of local initiatives in rural areas, generating diversity in the local economy and new jobs in rural areas in non-agricultural sectors;

- accrediting / authorizing training / education programs for people in the target group categories;

- the provision of activities by the public administration in line with the needs of SMEs;

- providing tax incentives to create new jobs;

- creating a competitive business environment based on entrepreneurship and a stable regulatory environment;

- concerted action between education, reindustrialization, export, RDI activity, development of parallel infrastructure with employment stimulation policies;

- promoting the 10 competitiveness segments mentioned in the Competitiveness Strategy 20142020 by increasing investment in these sectors with smart specialization potential, which will contribute significantly to quality jobs;

- promoting and developing social entrepreneurship.

\title{
4. Acknowledgements
}

This work was carried out through the Nucleus Program, with the support of ANCSI, project no. PN 16440106

\section{References}

[1] European Commission (2016), Annual report on European SMEs 2014/2015, SMEs start hiring again, DirectorateGeneral for Internal Market, Industry, Entrepreneurship and SMEs DOI 10.2873/76227, ISBN 978-92-79-62839-9

[2] Eurofound (2016), ERM annual report 2015: Job creation in SMEs, Publications Office of the European Union, Luxembourg

[3] European Commission (2016), Small Business Act Review

[4] M. Ghența, (2017), Characteristic of in-work poverty - a comparison between Romania and European Union, Journal of Economic Development, Environment and People (JEDEP), vol 6, nr3, ISSN 2285-3642

[5] D. Pașnicu; G. Tudose, (2016) The Main Structural Deficiencies on the Rural Labour Market and Employment Quality, The European Proceedings of Social \& Behavioural Sciences EpSBS, elSSN: 2357-1330

[6] D. Pîslaru (coordonator) (2016) Contribuţia IMM-urilor la creşterea economică - prezent şi perspective, elaborată pe proiectul: Îmbunătăţirea capacităţii instituţionale, de evaluare şi formulare de politici macroeconomice în 


\author{
(online) $=$ ISSN $2285-3642$ \\ ISSN-L = 2285 - 3642 \\ Journal of Economic Development, Environment and People \\ Volume 7, Issue 1, 2018 \\ URL: http://jedep.spiruharet.ro \\ e-mail: office jedep@spiruharet.ro
}

domeniul convergenţei economice cu Uniunea Europeană, Comisia Naţională de Prognoză, cod SMIS 27153

http://www.cnp.ro/inovatie/docs/seminar-studii-25-06-2012/Rezumat\%20studiu\%20IMM.pdf

[7] O. Nicolescu (coord.), (2016) Carta Albă a IMM-urilor din Romania, Consiliul Național al Întreprinderilor Private Mici și Mijlocii din România, ISBN 978-606-727-167-6, KeysFin (2015), Studiu IMM din Romania. 